\title{
Katby Mezei
}

Reading as Writing / Writing as Reading the reader and the decline of the writer / or the rise and fall of the slash

traduit par Christine Dufresne

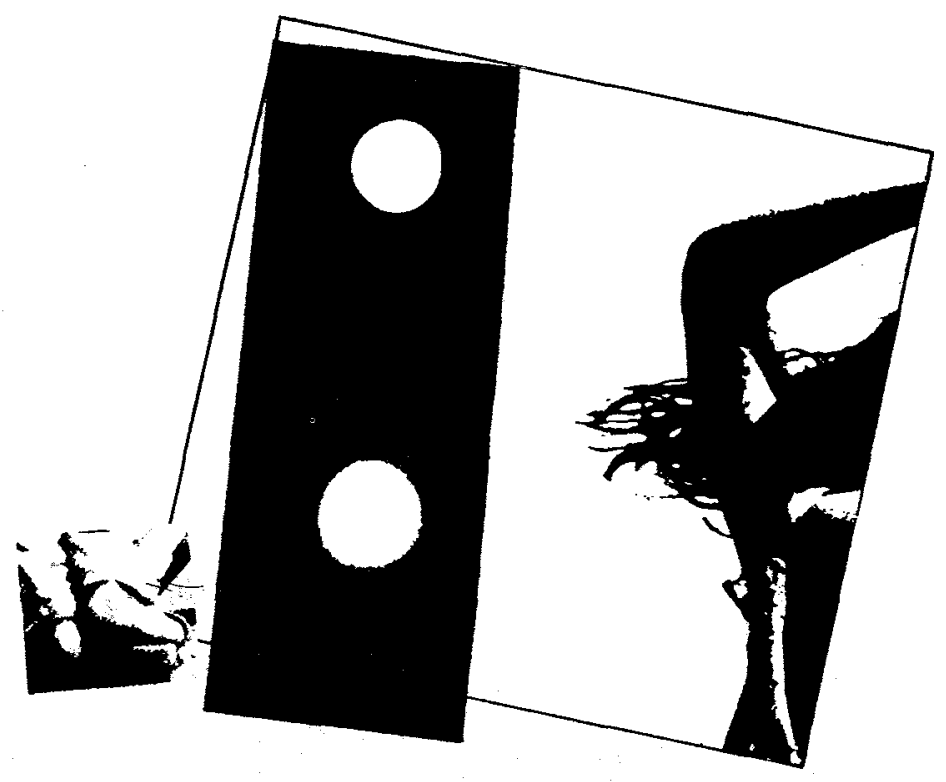


Current literary theory exalts the reader (as writer) at the expense of the author (as writer). The Reader has been called Super Reader or Amazing Reader while the author is Distant preferably, or Absent, at best implied, and certainly no longer Omniscient. From the pen/ typewriter/computer of Wolfgang Iser comes: the reader not the writer creates the work's meaning. On the one hand, this offends - why deny the author her due? why foreground the reader who may be lazy, haphazard, unfaithful, hostile or simply insensitive? But then here we are again in the jungle with the tree - does its falling have reality if no one hears it? does a text exist, have meaning if no one reads it ? (through we should remember Anne Frank writing her diary : to write was to live, to exist, in a world with no meaning). So must writers bow down in obeisance to the reader? At this point the slash (reading/writing) rises up/slants across/and throws out the following dilemmas, (the slash not divisive really, but not accepting either, ambivalent mostly). How does a reading complete a text? How does the writing prescribe a certain reading? ("A bad book is a book in whose mock reader we discover a person we refuse to become"). ${ }^{1}$ How does a male reader read a feminine text? As women readers do we then take up the task of not only revisioning texts but also of re-reading them/unreading them? Virginia Woolfs "the difference of view, the difference of standard." How differently do I and my

1 Walker Gibson, "Authors, Speakers, Readers, and Mock Readers," in Jane P. Tompkins, Reader-Response Criticism, Johns Hopkins University Press, 1980, p. 5. 
male colleagues read Hemingway ? Lawrence's Women in Love? Virginia Woolf? What of the "author-ity of experience" in reading and writing.

The emphasis on reading and readers arose, in part, as a reaction against new criticism's plunge into the text, its obsession with images, ambiguities and ironies, its horror of the nineteenth century biographical imperative - the investigation, the investiture of the author, and the consequent intentional fallacy - what did s/he intend to say ? Death to the author cried the critics. $^{2}$

The decline of the writer, the adoration of the pleasurable text, and its perplexed but orgasmic reader, arise naturally out of the continental drift towards linguistics, structuralism, semiotics, and deconstruction, for once you begin to code texts, chart their surface and deep structures, you follow the flow of the narrative line, like an undulating graph from author and sender to reader and receiver (narratee if you please). Theories zeroing on readers multiply : reader response, rexeption ästhetik, subjective criticism. Then you realize that there are different kinds of readers (as perceived and not perceived by the author) and here the slashes rise up wearily, valiantly once again - real/ideal/mock/ implied readers. You realize that reading is not an isolated, free-floating activity but one determined by and determining the literary institutions (schools/ movements/presses/literary conventions and genres).

Barthes dismissed the readable, praised the unread-

2 "The birth of the reader must be at the cost of the death of the author." Roland Barthes, Image, Music, Text. (New York, 1977) p. 148. 
able (illisible) which since we can't yet read, we can only write and do write as we read. Good heavens, is the writer creeping back in again ? But no, it is only the reader disguised as the writer. There she goes : the reader scrambling over the barrier/slash between reader/ writer, invading and appropriating. From the wrong side of the slash. Words/worlds are greener/blacker on the other side of the slash. The phallic slash.

Well, what then of writing as reading? We can see that a good writer must be a good reader, writing her text from other texts through blatant or subtle intertextuality, quotations, plagiarism : writing as stealing. Writing is also carefully reading the signs of the world about one, so one can write them down for others to read.

And the other side of the slash ? Reading as writing? Last year in a class we were discussing feminist literary criticism and reading a poem, "piecework," by Mary Howes. We paused at the line which read : "(it was so cold that winter $i$ almost got married: shelley winters)."3 A student told me the title of Shelley Winters' autobiography. I wrote the title down, the author down, and in the act of writing "Winters" caught the pun of the line which had escaped us all, readers all, writers none. By writing, said the same student, you are going through the same process the writer did.

Reading and Writing Now it is time to remove the slash. Genette said : the text is the nodal point where the writer writing and the reader reading meet. Text is the and between reader and the writer. And how

3 In Writing Right : Poetry by Canadian Women, Longspoon Press, 1982, p. 12. 
about translation as reading and writing - the perfect "and," given that another word for translation is equivalence. A dialectic is set up between two texts and two languages (the source text and language and the target text and language); translation becomes a compound act of reading and writing since the translator is both a reader (and interpreter of the source text) and a writer (of the target text). When I translate I read the text (as I did when I translated part of Louise Dupré's «La mémoire complice, doublement» / "the doubly complicit memory" for our first issue of TESSERA) then I reread the text and I re-read the text, and then I write in my language, my words : I write my reading and the reading has re-written my writing. Dupré said «L'usage de toute langue par l'homme-dominant a entraîné la sexualisation du langage et la femme se retrouve face à ce découpage du réel. Elle doit le traverser, le faire dévier pour arriver à se dire.» I translate : "The use of all language by the dominant-male has led to the sexualization of language, and woman finds herself facing an excision of the real. She must cross over it, make it deviate so she can find her own speech."

And woman as object of the sentence, (sentenced to the object), as reader moves over, crosses over the slash and becomes writer, speaking subject, creator of her own text.

And so I remove the slash : it falls, ambivalent as always, perhaps disconsolate, \& is replaced by an ampersand, cheerful, accommodating.

I have read

$\&$

I have written

$\&$ 